\title{
A Bridge Too Far? Music in the British War Film, 1945-1979
}

MERVYN COOKE

In his 2014 book Projecting Britain at War, Jeremy Havardi identifies four aspects of the national character which have been constantly promoted in British films concerned with the Second World War: chivalrous stoicism (the 'stiff upper lip'), understated humour in adversity, amateurish improvisation, and pride in the indomitability of the underdog. ${ }^{1}$ As usual in accounts of the British war movie, however, Havardi does not assess the crucial role played by film scores - which include some of the most famous in British movie history, now firmly lodged in the national consciousness - in helping to delineate these characteristics, beyond a few fleeting mentions of 'stirring' musical themes. This label and 'rousing' have always been by far the most common catch-all epithets associated with overtly patriotic film scoring, and they are also used repeatedly in the brief allusions to music in another recent survey of Second World War films. ${ }^{2}$

The present essay offers an assessment of scoring practices in a range of British war films from 1945 to the end of the 1970s, by which time the combat film in particular had grown moribund. It concentrates on the development of a distinctive martial idiom borrowed not only from the military but also from coronation music (which, somewhat ironically, is markedly Teutonic in its Meistersinger-like uplifting rhetoric and even in certain specific harmonic details), and action capers conceived in a spirit of almost comic-book schoolboy

\footnotetext{
${ }^{1}$ Jeremy Havardi, Projecting Britain at War: The National Character in British World War II Films (Jefferson, NC: McFarland \& Company, Inc., 2014), 6-7. Havardi notes that the national character under consideration is essentially that of the English rather than Britons as a united group: 'Naturally, any talk of a unified British identity is automatically contested and invites recrimination from non-English Britons who cling proudly to their rich cultural heritage. But the fact that English traits were projected onto the wider British nation makes the confluence of these terms inevitable' (ibid., 9).

${ }^{2}$ Howard Hughes, When Eagles Dared: The Filmgoers' History of World War II (London: I.

B. Tauris, 2012).
} 
adventuring strangely at odds with the horrific reality of modern warfare. The Suez crisis, the chilling paranoia of the Cold War, and the costly futility of Vietnam all helped transform the genre in the 1960s and 1970s into a more thoughtful reflection on the issues involved; yet even in the bleakest contexts the romanticized portrayal of resilience in the face of impossible odds could, with a little musical help, turn some of the worst defeats in British military history (Dunkirk, Arnhem) into a source of fierce national pride, and in its last gasps the combat genre continued to reflected a deep-seated nostalgia for the Second World War as a time of unambiguous moral purpose. German culture minister Michael Naumann once controversially declared that the UK was obsessed with the War, and the only country to have made this conflict the 'spiritual core of its national self, understanding and pride' ${ }^{3}$ Even a noted British film critic, writing in 1958 at the height of the war film's popularity, lamented that 'A dozen years after World War II we find ourselves in the really quite desperate situation of being, not sick of war, but hideously in love with it. ${ }^{4}$ This uncomfortable notion is often inescapably reflected in the upbeat musical style of postwar British scores illustrating the conflict.

Roger Manvell's characterization of British films made in 1939-41 when the country stood alone against Nazi expansionism also applies to the depiction of national behavioural traits in the war genre as a whole: 'it was in general a case of well-meaning amateurism giving place to a professionalism gradually acquired under stress', during which process there was a determination 'initially at least, to remain cultured and gentlemanly in the face of an enemy whom at heart [the British] despised as uncouth. ${ }^{5}$ Michael Powell's and Emeric Pressburger's $49^{\text {th }}$ Parallel (1941), with a score by Ralph Vaughan Williams, deftly balanced a quasi-documentary realism with propagandist content and entertainment value, and a

\footnotetext{
${ }^{3}$ Quoted in Havardi, Projecting Britain at War, 12.

${ }^{4}$ William Whitebait [George Stonier], 'Bombardment', New Statesman, 5 April 1958, 432.

${ }^{5}$ Roger Manvell, Films and the Second World War (South Brunswick and New York: A. S. Barnes and Company, 1974), 61, 62.
} 
detailed contemporaneous review in Documentary News Letter concluded that it had been a shrewd move to portray one character as a dilettante typical of the 'soft and decadent' type which many abroad perceived to be quintessentially British: 'Here the trick is to give your audience a picture of someone whom they wrongly think is representative, and to turn the tables on them by revealing him as unexpectedly tough. ${ }^{6}$ The music of war films, however, was often tough from the outset. In his near-contemporaneous account of both feature-film and documentary scoring during the conflict itself, John Huntley describes several scores for war pictures as 'stirring', 'patriotic' or 'powerful', 7 though some otherwise compelling movies were arguably weakened by old-fashioned melodramatic scoring, such as the romantic clichés of Noël Coward's In Which We Serve (1942), for which the music was composed by Coward himself (assisted by the uncredited Clifton Parker).

After the cessation of hostilities, the continuing usefulness of the medium of film for promoting the activities of the armed services coincided with a peak in cinema attendance, and a number of wartime features concerned with the conflict were successfully re-released: 'the commercial industry was soon to discover the apparently insatiable public interest in hitherto untold stories about the recent struggle in which, perforce, the services tended to hold pride of place', this appetite coinciding with 'a kind of public nostalgia for the nation's finest hour in the midst of Britain's postwar retreat from world power'. ${ }^{8}$ That finest hour, uniquely, had also seen century-old class divisions gradually eroded in the interest of the common good. Two early postwar films - both scored by Alan Rawsthorne in a lean, unsentimental and often dissonant idiom - achieved a new sense of realism while also doing well at the box office: The Captive Heart (1946) and The Cruel Sea (1952), which respectively reshaped the

\footnotetext{
${ }^{6}$ Quoted in ibid., 69.

${ }^{7}$ John Huntley, British Film Music (London: Skelton Robinson, n.d. [1947]), 52, 59, 74, 108, 112.

${ }^{8}$ S. P. MacKenzie, British War Films 1939-1945: The Cinema and the Services (London: Hambledon Continuum, 2001), 129-30.
} 
subgenres of prisoner-of-war drama and naval combat. The Wooden Horse (1950; music by Parker) also broke new ground for the POW movie with its understated and sparsely scored aura of quotidian realism. As the British film industry emerged from a severe financial crisis at the end of the 1940s, the war genre now bloomed thanks to the efforts of numerous directors, actors and composers who had themselves served in the conflict. ${ }^{9}$ By the mid1950s, war movies had become solid commercial bets, and in several instances proved to be the top-grossing films at the UK box office in their years of release. ${ }^{10}$

\section{Marching for king (and queen) and country}

The typical British war-movie soundtrack of the 1950s and 1960s was just as concerned with exploiting a memorable 'big theme' as the contemporaneous American western. Whereas the latter's sweeping melodies drew from the bright, diatonic optimism and pioneering dynamism of a nationalistic American sound which owed much to the style of Aaron Copland, for British film composers the prototype of what became an instantly recognizable patriotic soundworld was the music of Edward Elgar - considerably more old-fashioned, since the style concerned had originated in the 1890s and tapped directly into the aura of imperialistic grandeur that prevailed until the catastrophe of the First World War. Specifically, it was the set of five orchestral Pomp and Circumstance marches, four of which were composed in the first decade of the twentieth century, which spawned a whole host of imitations in both the cinema and concert hall. In the words of Michael Kennedy, Elgar's initiative had been 'an

\footnotetext{
${ }^{9}$ For further on the crisis of 1948-9, in which the British market was flooded with American films and all but seven of twenty-six British studios ceased production, see Geoffrey NowellSmith (ed.), The Oxford History of World Cinema (Oxford: Oxford University Press, 1996), 370 .

${ }^{10}$ These top-grossing films included The Dam Busters (1955), Reach for the Sky (1956) and The Battle for the River Plate (1957). The Bridge on the River Kwai (1957) won seven Academy Awards and was the world leader at the international box office in 1958. Also in 1958, Dunkirk netted the second highest UK receipts for the year and was selected, like River Plate, for a Royal Command performance.
} 
unprecedented effort to give the full-dress ceremonial military march something of a symphonic status.' 11

Elgar's first and fourth marches became the best known on account of the dignified and broadly expressive melodies in their central trio sections: that of the first was famously lyricized as 'Land of Hope and Glory', while that of the fourth bears the composer's characteristic marking nobilmente. 'Land of Hope and Glory', a tune which in its original instrumental form Elgar had declared would 'knock 'em flat' and of which early performances brought standing ovations from audiences yelling with enthusiasm, ${ }^{12}$ was launched in song form as the finale of the Coronation Ode, written for the crowning of Edward VII in 1902. (In the US, the melody became a popular choice for graduation ceremonies.) From here on, this patriotic style became inextricably associated with the pageantry and heraldry of royal rituals; among Elgar's other marches with royal associations were an Imperial March for Queen Victoria's Diamond Jubilee in 1897, and a Coronation March for George V and Queen Mary in 1911.The two most famous Pomp and Circumstance marches continued to be played prominently at modern royal events, such as the weddings of Prince Charles and Diana Spencer (1981) and of Prince William and Kate Middleton (2011). Elgar's celebrated trio melodies are predominantly diatonic, delivered by warm-hued strings and enlivened by an occasional dash of syncopation, and presented above solid bass lines plodding relentlessly along in the simplest of plain, repeated-crotchet rhythms and outlining strongly functional harmonic progressions - all of which characteristics are easily imitable.

The first Pomp and Circumstance march was used in the soundtrack to the short British instructional film If War Should Come (quickly retitled Do It Now once it had), made by the General Post Office Film Unit in 1939, while on the other side of the Atlantic 'Land of

\footnotetext{
${ }^{11}$ Michael Kennedy, 'Foreword' to Edward Elgar, Pomp \& Circumstance: Military Marches Nos. 1-5 (London: Boosey \& Hawkes, n.d. [1977]).

${ }^{12}$ Ibid.
} 
Hope and Glory' was played against the end credits of William Wyler's multi-Oscar-winning Mrs Miniver (1942), which took a sympathetic view of the plight of ordinary civilians in the Blitz-torn UK. A direct link between Elgarian pomp and circumstance and the increasingly rousing British movie scores of the 1940s and 1950s lies in the music of William Walton, who cornered the market for coronation marches with a more modern hue, and also transferred the idiom directly to the silver screen. Walton's Crown Imperial, which some dubbed 'Pomp and Circumstance March No. 6, ${ }^{13}$ was written in 1936 and intended for the coronation of Edward VIII, after whose abdication it instead accompanied the crowning of George VI in May 1937. Reviewing the first recording of Crown Imperial, critic William McNaught was decidedly unimpressed:

Walton's march is frankly a pastiche on a well-known model of ternary pomp and circumstance, with the regulation strut and swagger, plenty of plain diatonics, and a nobilmente tune in the middle. Though it keeps the game alive pretty well, it is unrepresentative of the composer, except as an example of competence, and is unlikely to survive. ${ }^{14}$

Walton was exempted from military service during the War on condition that he provide music for propaganda films - in the euphemism of the day, films 'of national importance'. In addition to scoring three such projects for Ealing Studios in 1941 and 1942, he provided the music for Leslie Howard's Ministry of Information production, The First of the Few (1942), and this gave him the opportunity indelibly to affix his neo-Elgarian patriotic spirit to what was by then an already legendary piece of military hardware. A superior fictionalized account of the life of Spitfire designer Reginald Mitchell, the film was furnished with a score from

\footnotetext{
${ }^{13}$ Kenneth Avery, 'William Walton', Music \& Letters 28/1 (January 1947), 1-11; 7.

${ }^{14}$ William McNaught, “'Crown Imperial”, Musical Times 78 (August 1937), 710.
} 
which extracts quickly became popular in the concert hall in the guise of the Spitfire Prelude and Fugue. The patriotic tone of the Prelude inhabits the same post-Elgarian soundworld as Walton's coronation march, while the boisterous Fugue originally accompanied shots of the assembly line working intensely to produce the prototype aircraft. Elsewhere in the score Walton employed the standard device of supplying musical quotations at appropriate moments, including a leitmotif from Wagner's Ring for the Nazi domination of Europe - a rather obvious trick he would later reprise in his rejected score to Battle of Britain (1969). The Spitfire Prelude and Fugue became firmly lodged in the public imagination as a wartime instrumental anthem, and (for example) was conducted by Malcolm Arnold in 1965 to mark the recent death of Winston Churchill. ${ }^{15}$

Crown Imperial was revived for the coronation of Elizabeth II in 1953, for which occasion Walton composed a companion piece, the more flamboyant Orb and Sceptre, which contains a splendid trio melody of which Elgar would justly have been proud. This 'spanking March', as Walton called it in correspondence at the time, was part of a carefully calculated 'orgy of Coronation music' (which also included a new setting of the Te Deum); he wanted the march to have 'a really singable tune in the middle, with words! I ought to have done it with [the] old one... ${ }^{, 16}$ The revival of patriotic and splendiferously ceremonial music of this kind for the Queen's coronation, an event symbolizing the optimism of a fresh generation of Britons emerging from postwar austerity into what was widely considered to be the birth of a new Elizabethan Age - promising a cultural richness akin to that of the era of Elizabeth I had a profound and immediate impact in the cinema. Even Miklós Rózsa aped the coronation-march style in his music to MGM's Young Bess, for example, a treatment of the

\footnotetext{
${ }^{15}$ Anthony Meredith and Paul Harris, Malcolm Arnold: Rogue Genius (Norwich: Thames/Elkin, 2004), 245. For further on The First of the Few, see MacKenzie, British War Films, 36-8, and (on Walton's music), Huntley, British Film Music, 59-60.

${ }^{16}$ Quotations from letters to Christopher Hassall, 14 February 1952, and David Webster, 22 January 1953, in Malcolm Hayes (ed.), The Selected Letters of William Walton (London: Faber and Faber, 2002), 215 and 222.
} 
early years of the first Elizabeth released - appropriately enough - in 1953. Laurence Olivier asked Walton to base the opening music for his film of Shakespeare's Richard III (1955) on Orb and Sceptre ${ }^{17}$ since the screenplay opens with an extended sequence during which Edward IV is crowned: this was a gratuitous attempt to cash in on the still-current coronation fever, since it involved not only the wholesale importation of lines from the wrong Shakespeare play but also (just in case the coronation context was not obvious enough) the insertion at the outset of a huge title card proclaiming the importance to the story of 'The Crown of England'. (The English crown also appears as a prominent image at the very end of Young Bess.) By this stage, however, Walton was heartily sick of such music and proceeded to tackle the Olivier commission with tongue firmly in cheek, facetiously inscribing his manuscript with the Italian phrase Con prosciuto, agnello e confitura di fragiole ("with ham, lamb and strawberry jam'). ${ }^{18}$ Nevertheless, the idiom remained alive in ceremonial occasions, as Arthur Bliss - appointed Master of the Queen's Music in 1953 - demonstrated when he composed his stentorian march Welcome the Queen in 1954.

This conjunction of coronation-fuelled nationalism with a refreshed dose of musical pomp and circumstance fed into British film music just as the war-movie genre began to acquire a new confidence. In 1952, the Battle of Britain film Angels One Five featured in its main-title sequence the rousing 'Royal Air Force March Past', here arranged by former Mosquito pilot John Wooldridge but co-composed back in 1919 by RAF music director H. Walford Davies; its Elgarian trio section was later added by Davies's successor, George Dyson. ${ }^{19}$ Another film about the RAF, Michael Anderson's The Dam Busters (released in the same year as Richard III) vividly told the tale of 617 Squadron and their legendary 1943

\footnotetext{
${ }^{17}$ Susana Walton, William Walton: Behind the Façade (Oxford: Oxford University Press, 1988), 243.

${ }^{18}$ Michael Kennedy, Portrait of Walton (Oxford: Oxford University Press, 1989), 194.

19 'A Brief History of RAF Music Services', http://www.raf.mod.uk/rafmusic/aboutus/historyofrafmusicservices.cfm (4 September 2015).
} 
bombing raid on three Ruhr dams vital to the German war effort, and Eric Coates's famous main-title march deliberately and unashamedly adopted the Elgarian nobilmente idiom, complete with plain-crotchet plodding bass line and some thoroughly familiar localized modulations. Coates declined to write a score for the film, but had fortuitously composed his (as yet untitled) Elgarian march in 1954, before the invitation to contribute music to the project reached him..$^{20}$ The remainder of the score was instead composed by Leighton Lucas, who let Coates's march speak for itself at the beginning and end and made only scant reference to it during his own cues. In 1956, Powell and Pressburger made an ambitious film of the first significant British victory of the War: the scuttling of the German pocket battleship Graf Spee in December 1939, after it had been hemmed in at Montevideo harbour by the Royal Navy following a thrilling cross-Atlantic pursuit. Meticulously researched, and partly filmed during official exercises with real ships, The Battle of the River Plate (US title Pursuit of the Graf Spee) featured a fine Prelude and March by Brian Easdale, who skilfully managed to avoid the more obvious Elgar-Walton clichés in the process. Powell recalled a preliminary screening of the film arranged for the benefit of the project's financiers:

There was a big theme that went with the big naval stuff, but we used Brian's Latin American music and the voice of Muriel Smith singing for the playout of the film. When the lights went up, we all knew we had a big hit. John [Davis] turned to me, and said, "Micky, why didn't you use that big naval theme of Brian Easdale's for the playout of the picture?"

Emeric said [in his Hungarian accent], "Vell, you see, John, the battle is over. The Graf Spee is no more, and we felt it would be nice to finish with the song and

${ }^{20}$ Michael Payne, The Life and Music of Eric Coates (Farnham: Ashgate, 2012), 208. 
the music as if it came from the shore of this neutral country who had been so kind to us." 21

It emerged that Davis, managing director of the Rank Organisation, wanted to delay the film's premiere until the next Royal Command performance (to be given in the presence of the monarch) and therefore wished it to conclude with a stirring naval scene. So the music was duly changed. 'But I didn't really agree with him...', recalled Powell: 'The idea of showing these great ships sailing into the sunset accompanied by this gay Latin American music was a good one. After such a victory, to crow over your defeated enemy would be really a little too much. ${ }^{, 2}$ Like Rawsthorne's film music, Easdale's score also reflected his ability to compose sophisticated, dissonant cues which avoided hyperbolic cinematic clichés.

Another significant British naval victory, this time from 1941, was celebrated in C. S. Forester's script for Sink the Bismarck! (1960), for which Parker composed a march with strong echoes of Elgar and Walton. ${ }^{23}$ Parker's march follows the Elgarian ternary model, with nervously bustling energy in the outer sections and a broad trio melody, trudging crotchet bass line, familiar harmonic twists, and occasional catchy syncopations; the trio melody is recapitulated by way of a stirring coda, again following the Elgarian pattern. According to James Marshall, Parker's piece was so authentically 'regal and patriotic' in tone that the film's early audiences 'were reported to be standing up for the end title, mistaking it for the

${ }^{21}$ Michael Powell, Million-Dollar Movie (New York: Random House, and London: William Heinemann Ltd., 1992), 347. Powell distilled his research for the film into another book, Graf Spee (London: White Lion Publishers, 1956), later retitled The Last Voyage of the Graf Spee. ${ }^{22}$ Powell, Million-Dollar Movie, 347.

${ }^{23}$ Forester, best known as the author of the Hornblower adventures set in Nelson's navy, wrote the screenplay in conjunction with his book Hunting the Bismarck (London: Michael Joseph, 1959). 
National Anthem. ${ }^{24}$ More unusual had been Parker's earlier march for the desert-war escapade Sea of Sand (US title Desert Patrol, 1958), a whimsical cue with folk-like modal inflections more reminiscent of Vaughan Williams and merely a (delicately played) snare drum lending the music a military feel. The film also included a catchy whistled theme, but this lost out in popularity to the prominence of Kenneth Alford's 1914 march 'Colonel Bogey' in David Lean's Bridge on the River Kwai (released in 1957), for which the film's composer Malcolm Arnold won an Academy Award. Thanks in part to a best-selling recording of Alford's tune by Mitch Miller and his band, the movie brought a belated hit status to 'Colonel Bogey', for which Arnold had composed a slick counter-melody which could also be played as a march in its own right (and became known as The River Kwai March). This was just as well, given that litigation from Alford's estate meant that for years afterwards no recording of the two tunes in combination could be issued. ${ }^{25}$ They were still kept well apart in the half-hour concert suite which the BBC commissioned from Christopher Palmer to mark Arnold's seventieth birthday in 1991, a venture which (thanks to Palmer's skill) lent the music a coherence it scarcely possessed in the film itself: 'the music is necessarily so episodic and fragmentary', wrote the arranger, 'that the only way to deal with it, as far as I could see, was to take the materials apart and put them together again' ${ }^{26}$ Although Alford's tune, which is jauntily whistled diegetically by the Allied troops in their harsh Japanese prison camp as a means of maintaining morale, might seem ineffectually naïve and unthreatening, anyone familiar with it from its earlier popularity during the War

\footnotetext{
${ }^{24}$ James Marshall, 'The Film Music of Clifton Parker', liner notes to recording by the BBC Concert Orchestra under Rumon Gamba (CHAN 10279, 2005), 5-13; 12. The repertoire on this disc was reconstructed and arranged by Philip Lane.

${ }^{25}$ Terry Cushion, 'Worth the money?', Beckus: The Quarterly Newsletter of the Malcolm Arnold Society 96 (Spring 2015), 4.

${ }^{26}$ Christopher Palmer, 'The Film Music of Sir Malcolm Arnold, Volume 1', liner notes to recording by the London Symphony Orchestra and Richard Hickox (CHAN 9100, 2000), 5$10 ; 5$.
} 
would have been aware that it had been lyricized in a manner designedly offensive to the luminaries of the Third Reich:

Hitler has only got one ball,

Göring has two but very small,

Himmler has something sim'lar,

But poor old Goebbels has no balls at all.

Not wishing to taint his project with vulgarity, Lean had opted to jettison these lyrics. Even so, the melody's popular status as an affront to the Axis powers meant that considerable embarrassment could still be caused as late as 1980 when, in a spectacular gaffe, a military band proudly played it to welcome the Japanese prime minister on his visit to Canada. ${ }^{27}$

Although both 'Bogey' and the 'Kwai March' inhabit a jocular soundworld which contrasts markedly with traditional Elgarian pomp and circumstance, Arnold nevertheless incorporated an unmistakable nod towards the Walton coronation-march idiom in a broad melodic strain half-way through his otherwise turbulent and grittily dissonant main-title overture. And the success of Kwai meant he was instantly typecast as a composer for this genre: 'Afterwards I was sold every bloody war movie that there was!', he moaned, ${ }^{28}$ and he went on to rework his own generic formulae in Dunkirk (1958) and The Heroes of Telemark (1965). Such typecasting also meant he was an obvious choice to help out Walton when his friend ran into difficulties while scoring the aerial epic Battle of Britain - an ill-fated last blast of the patriotic style considered in more detail below.

27 'Our band hit sour note for Japan's prime minister', Montreal Gazette, 6 May 1980, 1.

${ }^{28}$ Meredith and Harris, Malcolm Arnold, 167. 


\section{Spirit of adventure}

The Heroes of Telemark is a good illustration of how the 1960s British war movie and its music was not solely about stiff-upper-lip patriotism: indeed, the coronation-march idiom (which appears fleetingly in the film) dwindled somewhat as the genre became far more concerned with cultivating a heroic sense of adventure in which the excitement of the chase, the sheer ingenuity of the escapades, and the ability to overcome seemingly impossible odds were far more important - and cinematically thrilling. At times, the adventures portrayed on screen became so implausibly entertaining - and so far removed from the grim and bloody reality of warfare - that they seem more akin to schoolboy yarns than historical essays; and sometimes the tone of the War's portrayal even approaches that of a sports fixture. But the trend was often an accurate reflection of the first-hand accounts on which several films of this type were based. If the daredevil dressing up in German uniforms which allows the fictional Allied heroes of Where Eagles Dare (1968) to infiltrate a Nazi mountain stronghold seems far-fetched, such audacious impersonations of the enemy were indeed carried out with some success during the War, as in two historical accounts which were later filmed: Ill Met By Moonlight (book 1950; film 1957), in which a German officer is kidnapped on Crete by Allies working with the Greek resistance, and The Colditz Story (book 1952; film 1955), in which escape attempts are made by prisoners wearing German uniforms fashioned from blankets and cardboard, with insignia forged by secretly melting down lead pipes from the castle's lavatories. Colditz escape officer Pat Reid declared in the 'Apologia' to his memoirs that the inspiration provided by tales of this kind 'lives in men's memories and serves to keep alive the spirit of adventure. ${ }^{29}$ Allusions to sport, and sporting metaphors, abound in both real-life wartime accounts and fictional stories inspired by their authors' personal experiences of active service. For example, a (fictional) naval radar operator's reports of an approaching

${ }^{29}$ P. R. Reid, The Colditz Story (London: Hodder and Stoughton, 1952), [5]. 
enemy vessel are delivered in a 'clipped, easy' voice 'vaguely reminiscent of a cricket commentator's', ${ }^{30}$ and inventor Barnes Wallis in The Dam Busters likens Nelson's unorthodox low-level cannon shots to the notorious 'yorker' ball in the same sport. A (real) Admiral, who 'liked to talk a great deal about sport, while finding out what he really wanted to know', coolly waits to finish off his round of golf after seeing the signal recalling him urgently to the fleet - though divine punishment is later wrought when the only casualty of an enemy attack is his golf clubs, which have their heads blown off. ${ }^{31}$ (An identical fate befalls Michael Caine's golf clubs in Battle of Britain, impelling him to declare of the enemy bombing which has caused it: 'This is ridiculous!') Regarding war as a sport conveniently brought together British eccentricity, understatement, teamwork, self-discipline and above all a sense of fair play. ${ }^{32}$ And escaping from a prison camp - especially one so uncannily like an English boarding school as Colditz, with its after-lights-out dormitory escapades, and where the inmates' rough-and-tumble sports exercises were routinely followed by morally uplifting cold baths - simply became 'the greatest sport in the world'. ${ }^{33}$ Perhaps Evelyn Waugh wasn't far wrong when he famously declared: 'any one who has been to an English public school will always feel comparatively at home in prison'. ${ }^{34}$

In his preface to the memoir on which Powell's and Pressburger's film of Ill Met By Moonlight was based, W. Stanley Moss revealed that he had based his account on a diary he had kept at the time because he did not want to 'lose the spirit of light-heartedness and twenty-two-year-old exuberance (almost bumptiousness) with which it was written'; the book's prologue quotes a radio announcer as having described the tale thus: 'Of all the stories that have come out of the War this is the one which schoolboys everywhere will best

\footnotetext{
${ }^{30}$ Alistair MacLean, HMS Ulysses (Glasgow: William Collins Sons and Co. Ltd, 1955), 120.

${ }^{31}$ Powell, The Last Voyage of the Graf Spee, 40, 45, 78.

${ }^{32}$ Havardi, Projecting Britain at War, 20.

${ }^{33}$ Reid, The Colditz Story, 9, 70, 75.

${ }^{34}$ Evelyn Waugh, Decline and Fall (Harmondsworth: Penguin, 1937 [1928]), 188.
} 
remember'. ${ }^{35}$ The prologue, by Ian Moncreiffe, continues: 'It has always seemed that the conception of these expeditions embodies fully the Elizabethan qualities of daring and resource, and that same combination of love of adventure and love of one's country'. ${ }^{36}$ The schoolboy spirit shines through in Moss's account, in which a young sailor (as his vessel approaches the Cretan coast) 'seemed to be enjoying the whole affair much as a schoolboy at a pantomime' and a possible attempt by the occupying Germans to trick them from the shore with a signal lamp is described as a 'prank' ${ }^{37}$ As in the movies, German soldiers are dehumanized mannequins ('seated primly upright like tailors' dummies' as they pass by in a motorized convoy) and their General is 'a thick-set man' possessing 'most of the regular Teutonic features - thin lips, bull neck, blue eyes, and a fixed expression' ${ }^{38}$ The almost comic-book two-dimensionality of the treatment is unlikely to have fazed Powell, who in the preface to his own tie-in monograph to The Battle on the River Plate (written in the year before Ill Met was released) declared: 'My facts, times and dates are as correct as I can make them but this is not an historical document, it is an adventure-story'. ${ }^{39}$ In an attempt to combine solid symphonic writing with a local folk colour, Powell and Pressburger commissioned Cretan composer Mikis Theodorakis to compose the score for Ill Met, but encountered hostility from him when it emerged he considered both the British directors and wartime provocateur Patrick Leigh-Fermor to be 'interlopers': he said his fees would be paid to the Enosis revolutionary movement. The film had to be shot in the Alpes Maritimes because the Greek government felt that to make it on location in Crete would be 'a

\footnotetext{
${ }^{35}$ W. Stanley Moss, Ill Met By Moonlight: The Classic Story of Wartime Daring (London: Harrap \& Co., 1950; repr. London: Cassell, 1999), 13-14.

${ }^{36}$ Ibid., 16-17.

${ }^{37}$ Ibid., 25.

${ }^{38}$ Ibid., 94 and 105.

${ }^{39}$ Michael Powell, The Last Voyage of the Graf Spee (London: White Lion Publishers, 1976 [1956]), 6 .
} 
provocative act'. Powell later regretted having filmed the adventure in monochrome as he felt this made it look too much like a 'historical document' ${ }^{40}$

Two authors whose thrilling fictional tales had a profound influence on British war movies both made their names with best-selling action adventures at around the same time: Ian Fleming with his James Bond series of secret-agent novels (publication commencing in 1953; filmed from 1962 onwards), and Alistair MacLean with his eclectic output of action thrillers, several of which were set in the War (publication commencing in 1955; filmed from 1961 onwards). Fleming's Bond led a constantly womanizing and headily fast life which left virtually no time for conventional patriotism: his forays against the enemies of the state were more in the nature of single-handed gladiatorial combat, laced with a savoury tinge of personal vendetta. With a new Cold War ruthlessness and lack of sentimentality, these were modern action adventures par excellence, and John Barry's celebrated pop-orchestral scores for the early instalments in the (still ongoing) film franchise caught the mood of the times perfectly. At the same time, traditional British behavioural traits shine through the contemporary sheen. A high-ranking officer of the Soviet Foreign Ministry in one of the books, for example, wonders why British agents do such dangerous work for so little reward, and concludes it is 'the Public School and University tradition. The love of adventure. ${ }^{41} \mathrm{~A}$ Soviet chess Grand Master later declares: 'The English pride themselves on their eccentricity. They treat the eccentric proposition as a challenge. ${ }^{42}$

MacLean's debut novel HMS Ulysses, on the other hand, was a grimly serious account of the Arctic naval convoys, based on the author's first-hand wartime experiences: quite unlike his often tongue-in-cheek later adventures, the book shared a kinship with Nicholas Monsarrat's starkly realistic 1951 novel (also semi-autobiographical), The Cruel

\footnotetext{
${ }^{40}$ Powell, Million-Dollar Movie, 349-50, 358-9.

${ }^{41}$ Ian Fleming, From Russia with Love (London: Jonathan Cape, 1957; new edition, with an introduction by Tom Rob Smith, London: Vintage, 2012), 58.

${ }^{42}$ Ibid., 89.
} 
Sea, which was memorably filmed in 1953 . The movie version preserved the sometimes deeply uncomfortable moral dilemmas of Monsarrat's tale, and also broke significant new ground in its soundtrack by making prominent use of what MacLean in his own novel described as 'the monotonous, nerve-drilling pinging of the Asdic', ${ }^{43}$ referring to the antisubmarine sonar technology which in The Cruel Sea becomes something of a character in its own right. The tension these dogged bleeps generate sometimes obviates the need for an orchestral score to fulfil this function, and it was to remain a stock device in later Cold War naval dramas. Rawsthorne's economical nondiegetic music elsewhere took a notably fresh approach to the genre, with its characteristically gritty dissonances and resultant sense of uncomfortable struggle rather than easy patriotism. (Rawsthorne's strong compositional personality, also heard in his music for the real-life wartime story The Man Who Never Was (1955) - for which he incorporated a German spy’s Morse-code rhythms into his score, generating tension in much the same way as the 'pinging of the Asdic' in the naval dramameant that he could achieve this without lapsing into dissonant film-noir clichés of the kind heard in Francis Chagrin's music for The Colditz Story and John Addison's for Reach for the Sky, both of which seem overdone for modern tastes.) MacLean pauses in his story to make several important points about the sailors' attitudes towards the war, in a timely reminder that those on active service (as in the First World War) did not indulge in luxuries such as hatred of the enemy or patriotism. These two things, he recalls, were 'never taken into the slightest account ... never mentioned, never even considered', and were only propagated by 'the sentimentalists at home' and 'the propagandising purveyors of nationalistic claptrap' in the press:

${ }^{43}$ MacLean, HMS Ulysses, 149. 
the synthetic national hatreds and the carefully cherished myth of King and country $\ldots$ are nothing and less than nothing when mankind stands at the last frontier of hope and endurance: for only the basic, simple human emotions, the positive ones of love and grief and pity and distress, can carry a man across that last frontier. ${ }^{44}$

Early on in his first book to be filmed, The Guns of Navarone, MacLean also reflected that the conflict was 'not a war of bugle calls and roaring engines and magnificent defiance in the clamour of battle' but one 'of patience and endurance and stability, of cunning and craft and stealth, and these were not commonly the attributes of youth... ${ }^{45}$ However, the movie treatment of this tale (which did well at the box office) entirely lacked these serious undercurrents by adopting the customary Hollywood-style big-budget sweep, with a suitably traditional orchestral score by Dimitri Tiomkin rounded off with old-fashioned allusions to Thomas Arne's patriotic tune 'Rule, Britannia!' when Royal Navy destroyers finally come to the rescue of the valiant commandos.

By the time the long-delayed sequel Force 10 from Navarone was filmed in 1978, the inevitable choice of composer had now become Ron Goodwin, who single-handedly transformed the soundscape of the British war movie during the 1960s and generated some of the most viscerally effective scores ever conceived for the genre. With only occasional allusions to the coronation-march idiom, Goodwin's music was characterized by a fresh formula ideally suited to unsentimental action scenes, and most of his scores showcased the kind of thrilling 'big theme' which served to remind spectators that, in many respects, these British war adventures had now become a direct equivalent to the American western. (This parallel had been made particularly explicit in a film about an earlier conflict, Zulu (1964),

\footnotetext{
${ }^{44}$ Ibid., 192.

45 Alistair MacLean, The Guns of Navarone (Glasgow: William Collins Sons and Co. Ltd, 1957), 24.
} 
which thanks to its arid geographical setting and almost cowboy/Indian portrayal of the opposing sides even looks like a western - and it was furnished with dynamic music by Barry to match.) Goodwin's action formula was honed in 633 Squadron (1964), a fictional tale of the exploits of a daredevil Mosquito squadron based on the far more sombre novel by Frederick E. Smith, of which the tragic ending and unpleasant character flaws in certain of the pilots were both significantly toned down for the film. ${ }^{46}$ Smith's novel nevertheless (like Bond's missions) perpetuates both the growing myth that a single daring act of heroism can halt an entire enemy initiative ('the Germans are on something big. Something so big, in fact, that it might have a far-reaching effect on the war if it isn't destroyed') and that the Norwegian landscape on which the bombers inflict their damage might as well be in Monument Valley ('another redskin will bite the dust' as the mountain collapses). ${ }^{47}$ Goodwin's exciting main-title theme is propelled along by spirited hemiola rhythms which he claimed had been inspired by the numbers $6(=6 / 8)$ and $3(=3 / 4)$ in the film's title. ${ }^{48}$ The unmistakable feel of a western-like 'big theme' stems entirely from this catchy rhythmic underpinning, which conceptually recalls the hard-driving, dislocated rhythmic accompaniments for many scores to Hollywood westerns and related genres, from Elmer Bernstein's trailblazing The Magnificent Seven (1960) to John Williams's Star Wars (1977). In its second section Goodwin's theme lapses into a more conventional march rhythm, and the contrast between the swirling compound- and triple-time opening melody and the foursquare march passage parallels a similar metrical shift in Addison's theme for the earlier RAF drama Reach for the Sky (1956), which recounts the life of legless fighter ace - and onetime Colditz inmate - Douglas Bader. In both scores, the buoyant triple-time rhythms and swirling

\footnotetext{
${ }^{46}$ Frederick E. Smith, 633 Squadron (London: Hutchinson, 1956; repr. Cassell, 2003).

${ }^{47}$ Smith, 633 Squadron, 194, 195.

${ }^{48}$ Jeff Bond and Alexander Kaplan, 'Break for the Fjord!', liner notes to CD 633 Squadron/Submarine $X$-1, original motion picture soundtracks, FSM Silver Age Classics 8/4 (2005), 2-11; 6 .
} 
accompanimental figures recall the swashbuckling naval adventures of an earlier age and put the listener more in mind of an aerial ballet than airborne carnage. In addition to the 'big theme', the formula Goodwin laid down here also includes economical thriller-type cues for moments of tension, often featuring spine-tingling octatonic discords and obsessive reiterations of terse rhythmic motifs; the generic nature of such cues meant that some of the less immediately identifiable music from 633 Squadron could be recycled in the later film Attack on the Iron Coast (1968; original music by Gerard Schurmann) without incongruity.

As if to illustrate how traditional British stereotypes can easily lead to uncritical assumptions, American film buffs Jeff Bond and Alexander Kaplan describe Goodwin's energetic themes as having 'so defined the feeling of British stiff-upper-lip militarism that they qualify for anthem status among war-movie buffs'. ${ }^{49}$ Anthem status they may well have acquired, but the sheer excitement generated by this kind of scoring is worlds apart from the dignified restraint of the proverbial stiff upper lip; and neither is the whole 633 Squadron main-title cue a march, as these authors incorrectly state. More of an Elgarian flavour creeps into Goodwin's main-title music for Operation Crossbow (1965), in which the action cues add another ingredient to the basic formula: a persistent four-note descending ostinato, used in both major (Lydian) and minor modes, as a simple tension-generating device in a manner not dissimilar to the more understated moments in some of Barry's contemporaneous Bond scores. The parallel with 007's adventures persists in the way in which the climactic destruction of the Germans' V-weapon base 'echoed the obligatory destruction-of-thevillain's-compound finale of many of the James Bond films'; after a poor start at the US box office, MGM (for whose British arm Goodwin was a staff composer) wanted to retitle the

${ }^{49}$ Ibid., 5 . 
film The Great Spy Mission in a seemingly cross-generic marketing strategy. ${ }^{50}$ Made in 1967 but not released until 1969, Submarine X-1 (1969) toted the kind of knife-fight between frogmen which had been a memorable feature of the Bond movie Thunderball (1965); as with Crossbow, some of Goodwin's action music was not in the event used, but the project benefited from a main-title 'nautical anthem brimming with optimism'. 51

Where Eagles Dare (1968) is arguably Goodwin's finest achievement in the war genre. This is another Bond-like action yarn featuring an enemy fortress in a spectacular Alpine setting, a wise commander-in-chief keeping a close listening watch on the progress of the mission back in the UK - just like Bond's boss, 'M' - and a hero (Major Smith) whose description as 'a man of resource... A man of infinite resource ... who can extricate himself from positions of utmost difficulty' is worthy of 007 himself. ${ }^{52}$ MacLean unusually worked on both the screenplay and novel simultaneously; and, while both incarnations of the story take the wise-cracking sang froid of the two heroes to fairly ludicrous extremes (at one point prompting one of the token female characters to suggest 'dryly' that they should 'audition for a turn on vaudeville'), ${ }^{53}$ the book is a rather grimmer affair in places. For example, in the novel Smith is shot in the hand much earlier and more severely than in the film and his wound is in danger of impairing his escape from the Schloss (as well as making his subsequent superhuman feats on the cable-car roof even more implausible). In the film,

\footnotetext{
${ }^{50}$ Jeff Bond, Lukas Kendall and Jeff Eldridge, 'What's the Buzz?', liner notes to CD Where Eagles Dare/Operation Crossbow, original motion picture soundtracks, FSM Silver Age Classics 6/21 (2003), 19-26; 21.

${ }^{51}$ Jeff Bond and Alexander Kaplan, 'Prepare to Submerge!', liner notes to CD 633 Squadron/Submarine X-1, original motion picture soundtracks, FSM Silver Age Classics 8/4 (2005), 12-18; 14. This was the first release of the $X-1$ soundtrack, based - as with other bonus tracks in this series - on Goodwin's own private tape recordings from the studio sessions. The same submarine story had previously been told, with a less melodically memorable and less genre-specific score by Arthur Benjamin, in Above Us the Waves (1955). ${ }^{52}$ Alistair MacLean, Where Eagles Dare (Glasgow: William Collins Sons and Co. Ltd, 1967; new pbk edn HarperCollins, 2004), 112. The words are spoken by the German-born agent Heidi in such implausibly formal English that she claims to have remembered the description verbatim from a London source: 'They have a funny way of talking in Whitehall'.

${ }^{53}$ Ibid., 152.
} 
Smith's superficial hand injury becomes a joke when he merely says 'Damn!' and remains otherwise unscathed after more than two hours successfully dodging everything the mighty German military machine can throw at him. The book is unusual in MacLean's output in containing several references to music, performed in the Austrian hostelries and honoured as diegetic cues in the movie: 'Schrammel music, hauntingly and nostalgically evocative of a kindlier and happier age, flooded through the open doorway... There was a time and a place for Schrammel music and this wasn't it. ${ }^{, 54}$

The strength and freshness of Goodwin's nondiegetic score for Where Eagles Dare lie in the jettisoning of the major-key triumphalism of his earlier war assignments in favour of minor-key music of dogged determination. The obsessively repeated snare-drum rhythm accompanying the gradual nocturnal approach towards the camera of the Junkers 52 aircraft above breathtaking Alpine scenery, on its way to drop the Allied agents behind enemy lines, is a potent distillation of similar rhythmic ostinati in his earlier scores, and in this instance a reflection of the director's wish that there would be no competition between the sound of the aircraft's engines and heavy orchestral scoring. ${ }^{55}$ Once the full orchestra gets underway with its grim march, Goodwin adopts the time-honoured tradition of equating muscular counterpoint with struggle or flight, basing his fugato section on a diminution of the ascending minor-scale tetrachord which serves as a simple main motif elsewhere: as Rózsa had been before him, he was fully aware of the historical symbolism of the fuga which underlies gestures of this kind, recalling that the passage had been inspired by 'people following each other around and dodging away from each other'. ${ }^{56}$ Much of the rest of the

\footnotetext{
${ }^{54}$ Ibid., 86.

55 Jeff Bond, Lukas Kendall and Jeff Eldridge, 'Die, Nazi, Die!', liner notes to CD Where Eagles Dare/Operation Crossbow, original motion picture soundtracks, FSM Silver Age Classics 6/21 (2003), 2-16; 7.

${ }^{56} \mathrm{Ibid}$. On the symbolism of fugal techniques in film scoring, see Mervyn Cooke, A History of Film Music (Cambridge: Cambridge University Press, 2008), 99-100, and Miklós Rózsa,
} 
score is tautly economical, with the music often restricted to simple parallel chordal motion set against determined pedal points and snare-drum ostinati maintained at some considerable length. The most striking inspiration is the intensely chromatic string music for the climactic hand-to-hand combat on the icy cable-car roof, in which the component parts of Goodwin's 'sort of twelve-tone version' ${ }^{57}$ of the fugato interlock with a claustrophobic logic of which Lutosławski might well have been proud.

\section{A bridge too far?}

As the vivid and seemingly never-ending horrors of the Vietnam War became widely understood by the public in the late 1960s, both mindless patriotism and escapist wartime action - even if firmly cast in a historical setting - not surprisingly went out of fashion in the cinema. If the Bond formula lived defiantly on, it did so in part because it continued (somewhat nostalgically) to reflect the hard certainties of a bygone era, Fleming having died in 1964 'before scepticism towards our governmental masters congealed into outright cynicism, before thrillers became laced with paranoia and deep, dark ambivalence. The Bond novels [from our modern standpoint] return us to a world of courage, ingenuity and moral clarity... ${ }^{58}$ For the British, the Suez crisis of 1956 had already uncomfortably demonstrated just how little the country's former imperial might was worth in the modern era, and this realization may well have subconsciously shaped the more adult flavour of war films from the later 1950s onwards (for example, Ice Cold in Alex (1958; music by Lucas) and Bridge on the River Kwai), with their flawed characters - sometimes reliant on alcohol for Dutch courage and on the verge of cracking under pressure - and willingness to tackle major defeats

Double Life: The Autobiography of Miklós Rózsa (Tunbridge Wells: The Baton Press, 1982), 24.

${ }^{57}$ Bond et al., ibid.

${ }^{58}$ Sam Bourne [Jonathan Freedland], introduction to Ian Fleming, Dr No (Jonathan Cape, 1958; London: Vintage, 2012), xvii. 
such as that portrayed in Dunkirk, Arnold's score for which nevertheless includes a lush Waltonian main-title march. Dunkirk was a success at the box office in 1958 and was also given a Royal Command performance, but critic William Whitebait wrote a scathing review which reflected on its cultural and political context:

So while we 'adventure' at Suez, in the cinemas we are still thrashing Rommel - and discovering that he was a gentleman! - sweeping the Atlantic of submarines, sending the Few to scatter Goering's many. The more we lose face in the world's counsels, the grander, in our excessively modest way, we swell in this illusionary mirror held up by the screen. It is less a spur to morale than a salvo to wounded pride; and as art or entertainment dreadfully dull. ${ }^{59}$

Up to this point, according to groundbreaking director Lindsay Anderson, the British cinema had been as 'snobbish, emotionally inhibited, wilfully blind to the conditions of the present, [and] dedicated to an out-of-date, exhausted national ideal' ${ }^{60}$ In her study of the US combat film, Jeanine Basinger notes that between 1965 and 1975 the genre at last came to be 'tested' by parody, satire and a sense of 'opposite reality' ${ }^{61}$ In the UK, too, satire and black comedy memorably reared their combined heads in Richard Lester's singular Second World War project How I Won the War (1967), with music by Ken Thorne. More historically remote wars were commandeered for this purpose, too, with Tony Richardson's highly inventive The

\footnotetext{
${ }^{59}$ Whitebait, 'Bombardment'.

${ }^{60}$ Quoted in James Chapman, Past and Present: National Identity and the British Historical Film (London: I. B. Tauris and Co. Ltd, 2005), 196.

${ }^{61}$ Jeanine Basinger, The World War II Combat Film: Anatomy of a Genre (New York: Columbia University Press, 1986), 210.
} 
Charge of the Light Brigade (1968) in equal parts a 'savage condemnation' of Britain's past imperial control and a direct response to Vietnam. ${ }^{62}$

Although both Battle of Britain (1969) and A Bridge Too Far (1977) are characterized by a greater sense of realism in their action sequences than had been the norm in earlier movies in the genre, these two big-budget films demonstrate how the conventional Second World War action genre somewhat uneasily tried to adapt itself to this new context. In both cases, a tension between outmoded gung-ho attitudes and the modern bleakly pessimistic view of warfare and the suffering it engenders is reflected in the films' scores, one of which was summarily rejected by the producers and the other remained arguably inadequate to its task. Both projects were technically British productions but, as had by this stage become the norm, were heavily indebted to US financiers and therefore kept a keen eye on the transatlantic market (reflected in the prominent casting of American actors in leading roles, a trend in evidence since The Guns of Navarone): by the late 1960s the UK film industry was 90\% funded by the US, and Battle of Britain (produced by 007 mogul Harry Saltzman) has been cited as a clear example of the blockbuster-mentality overspending which directly caused the industry's fortunes to slump in the following decade. ${ }^{63}$ Both films tap into the by now long-established Hollywood tradition of lavish action-driven epics based on the detailed recreation of historical events, which Basinger views as the combat genre's 'final evolutionary stage: the true war has been removed, and in its place is its filmed replica. This finally makes the war a legendary story - fully distanced and mythic - suitable to be one of our national stories for all time.' Analysing The Longest Day (1962), Battle of the Bulge

\footnotetext{
${ }^{62}$ Duncan Petrie, 'British Cinema [1960-95]: The Search for Identity', in Geoffrey NowellSmith (ed.), The Oxford History of World Cinema (Oxford: Oxford University Press, 1996), 604-13; 609.

${ }^{63}$ Ibid.
} 
(1965) and Tora! Tora! Tora! (1970), she laments in particular the inability of these films' all-star casts to engage the audience in effective character development. ${ }^{64}$

Walton's return to film scoring with Battle of Britain, after a lacuna of some fourteen years, was a far from happy experience. ${ }^{65}$ He wrote to Arnold in September 1968 saying he had 'rashly' accepted the commission and asked him to conduct the recording of the score to give him some moral support. Walton's wife remembered that he was 'determined to write something rousing and British, something people would remember. It also amused him to discover that the German armies had marched into battle to the accompaniment of music by Wagner; William felt he could make good use of this. ${ }^{66}$ The outcome of this discovery was some Siegfried-derived motivic material associated with the Luftwaffe pilots, and yet another coronation-style march for the RAF. The latter no longer came easily, however. 'No sign of a tune!', Walton informed Arnold (who once claimed he had helped his friend compose Orb and Sceptre), and continued: 'Every time I think of one I find I've written it before. ${ }^{67}$ (In another RAF-set film released in 1969, the low-budget Mosquito Squadron, Frank Cordell had no qualms about including in his main-title march a melody which is embarrassingly similar to that of the trio section in Orb and Sceptre, sitting oddly alongside muscularly rhythmic adventure scoring of the Goodwin variety.) Eventually the new Walton march duly materialized, as part of a somewhat meagre score amounting to a mere twenty minutes, of which the undoubted high point was a scherzo for dog-fighting sequences which had to be heavily arranged by Arnold, who supplied some transitional material in order to patch together repeats of identical passages: a substantial part of the manuscript for this cue is in

\footnotetext{
${ }^{64}$ Basinger, The World War II Combat Film, 188, 192.

${ }^{65}$ For a full account, see Kennedy, Portrait of Walton, 237-40.

${ }^{66}$ Susana Walton, William Walton, 97.

${ }^{67}$ Meredith and Harris, Malcolm Arnold, 278. The claim about the 1953 coronation march was made by Arnold in a radio interview in 1996: see ibid., 278 n. 36.
} 
Arnold's hand. ${ }^{68}$ Newspaper critic Edward Greenfield attended a recording session in April 1969, at which everything apart from the new march was conducted by Arnold. Annoying Walton by declaring that his march, which the composer had conducted himself, was rather too close to the idiom of Elgar's Second Symphony, Greenfield was nonetheless blown away by what he described as this 'uninhibited, youthful, exciting' and 'grand super-dambusting' piece: 'With an outrageous whooping on the horns comes a grand patriotic tune to out-type and out-glory any that Sir William has yet written, whether for films or coronations' ${ }^{69}$

The first Walton knew of the rejection of his score was when a journalist phoned to ask him about it. It emerged that the United Artists executives, who had been sent the music in isolation from the film, had at first deemed it to be of insufficient length for a soundtrack album; in a rather half-hearted measure, this concern resulted in an interim request via his agent that Walton add a new 16-bar section to the middle of the march. The composer responded to his agent (with a reference to Elgar's most famous trio melody) that: 'If they want another "Land of ho. and glo." it's not on the cards - for it is one already on a slightly smaller scale in that it doesn't last quite as long. ${ }^{70}$ The whole score was then rejected, Barry declining to provide a replacement and the task in turn passing - perhaps inevitably - to Goodwin. Walton's close friend Olivier, playing the part of RAF supremo Sir Hugh Dowding, retaliated by threatening to have his name removed from the film's credits if none of the original score was used: in consequence, the dogfight scherzo ('Battle in the Air') was reinstated (and included on the soundtrack album), and Walton's music was not given the slightest competition from sound effects, where were memorably suppressed during the entire aerial sequence. In some release prints the march was also retained, underscoring Dowding's

\footnotetext{
${ }^{68}$ Piers Burton-Page, Philharmonic Concerto: The Life and Music of Sir Malcolm Arnold (London: Methuen, 1994), 104.

${ }^{69}$ Guardian (29 April 1969), 10.

${ }^{70}$ Quoted in Kennedy, Portrait of Walton, 239.
} 
final appearance (for which moment it had been specifically conceived). ${ }^{71}$ A DVD release of the film in 2004 for the first time offered Walton's rejected score as an alternative music track, but (if accurately reconstructed) the cue locations are somewhat puzzling: the glowing patriotic march accompanies the opening main-title sequence of solely German pomp and circumstance, not the British, and one of the Siegfried-derived cues illogically accompanies a narrowly averted wheels-up landing by an RAF Spitfire. ${ }^{72}$

Goodwin's much more ubiquitously spotted replacement score, in addition to reworking the formulae thoroughly familiar from his earlier war features, gave the Germans their own cheerily diatonic march as a clearer recognition feature, at first entitled 'Luftwaffe March' and later (when it became a military-band hit in Anglophone countries) going under the less treasonable title 'Aces High'. The sheer jolliness of this naïve-sounding music was by no means unique in later British war movies, others of which applied this more generalpurpose militaristic style to the British as well as the Germans. The march of this type in Goodwin's score to Force 10 from Navarone (1978), his last for a major feature, might even be thought to mark out the film 'as something of a comedy. Stylistically, it recalls $19^{\text {th }}$ century European military marches rather than the inherently "British" harmonic language of the composer's other war scores' ${ }^{73}$ This film, however, was another lightweight MacLean adventure not as likely to trouble the moral conscience as much as a purportedly accurate account of a major historical set-piece: the humiliating British defeat attendant on the

\footnotetext{
${ }^{71}$ Susana Walton, William Walton, 98. British Prime Minister Ted Heath, an accomplished amateur musician, eventually retrieved most of Walton's manuscript from UA to mark the composer's seventieth birthday in 1972, but it lacked the 'Battle in the Air' - over which they claimed legal ownership since it had been used in the film as released (ibid., 211). For further on Walton's rejected score, see Gergely Hubai, Torn Music. Rejected Film Scores: a Selected History (Beverly Hills, CA: Silman-James Press), 91-3.

${ }^{72}$ Hubai asserts that in reconstructing the soundtrack for the DVD release the film's first assistant editor, Timothy Gee, 'knew exactly where each piece of the unused score was supposed to appear' (ibid., 93).

${ }^{73}$ Jeff Bond and Lukas Kendall, 'A Return to Force', liner notes to CD Force 10 from Navarone, original motion picture soundtrack, FSM Silver Age Classics 9/4 (2006), 3-14. As with Submarine $X-1$, this CD release was mastered from Goodwin's personal stereo tapes.
} 
massive airborne assault on the Arnhem and Nijmegen bridges in September 1944, known as Operation Market Garden, which as musically depicted in A Bridge Too Far treads an uncomfortable middle ground between traditional patriotic defiance and the film's gritty depiction of what Basinger terms 'the futility of war and the wretchedness of a specific military debacle'. ${ }^{74}$ Addison's jolly main-title march, of a kind he had already written for $I$ Was Monty's Double (1958; US title Hell, Heaven or Hoboken), jars on its first appearance, materializing as it does immediately after sombre newsreel footage; there are momentary nods to the Elgar-Walton lineage, but (apart from one dissonant flattened sixth in the bass) the idiom is again more rooted in the nineteenth-century diatonicism of the parade ground. Admittedly there is relatively little music in what is a very long film, and the violent scenes are left unscored; but the recapitulations of the march repeatedly strike an inappropriate tone, and other brief linking cues either inhabit a romantic soundworld vaguely reminiscent of Rachmaninov or (bizarrely) even suggest a comic interpretation of events, as when US troops approach their objective along a country road and the music switches from a furtive mood to an amiable march before being cut off by sudden explosions. At the start of the end credits, the march is faded in for the final time after an appreciable pause, perhaps indicating a recognition on the part of the filmmakers that such cheerful music is by no means the ideal response to the closing scenes of carnage, dejected troops, devastation, and displaced civilians. (Interestingly, one commentator who admires Addison's march describes it as 'stirringly heroic and yet bittersweet', but quite erroneously believes it to be a 'minor key melody'. ${ }^{75}$ ) Such caution had also been in evidence in the soundtracks for two 1950s war films. In The Dam Busters, Coates's march is drowned out by the homecoming bombers' engine noise and is briefly sneaked back in at a discreetly low volume beneath a radio announcer's report of the mission, needing to be faded back out into solemn silence when it

\footnotetext{
${ }^{74}$ Basinger, The World War II Combat Film, 331.

${ }^{75}$ Hughes, When Eagles Dared, 216.
} 
emerges that eight of the bombers failed to return; as in A Bridge Too Far, the march is faded back in again for the end credits rather than starting in a triumphant blaze. And in Dunkirk Arnold's march is recapitulated for the triumphant arrival, cavalry-like, of the Royal Navy, but is quickly replaced by sombre underscoring as a voice-over reminds us of the appalling human cost of the defeat.

Addison had himself served as a tank commander in the aftermath of the Normandy landings (though not, as often reported, during Market Garden itself). Perhaps, like the project's screenwriter William Goldman, he believed the battle to have been the last 'in which any of the old romantic notions of war held true', Goldman directly contrasting it to the 'brutal and dirty' Battle of the Bulge which followed. ${ }^{76}$ The traditional stiff-upper lip was still very much in evidence during the chaotic struggle for the Rhine bridges. The Arnhem veteran Lt. Colonel John Frost, watching actor Anthony Hopkins portraying him on location trying frantically to dodge a German sniper's bullets, advised him: 'you're running too fast ... you would never run that fast. You have to show the Germans and your own men your contempt for danger. ${ }^{77}$ This sentiment would not be out of place coming from one of the numerous stereotyped Sandhurst officers in MacLean's fictional war adventures. And it cannot be denied that, like so many of the film-score marches described in this essay, Addison's musical response to the film subsequently became a staple of the real-life militaryband repertoire.

Two other British war films from the late 1970s showed (in very different ways) how more resourceful composers could still keep audiences on the edge of their seats. For the 'what if' scenario of The Eagle Has Landed (1976) - a kind of Where Eagles Dare in reverse,

\footnotetext{
${ }^{76}$ William Goldman, William Goldman's Story of A Bridge Too Far (London: Coronet/Hodder and Stoughton, 1977), n.p. In generally listing the various members of any film production responsible for ensuring its artistic success, Goldman overlooks the composer - and, not surprisingly, Addison's score is never mentioned in the course of the book.

${ }^{77}$ Ibid.
} 
in which crack German paratroops infiltrate a Norfolk village in a bold attempt to kidnap Churchill - Lalo Schifrin composed a memorably tense score, including a main-title march which avoided well worn British and Continental stereotypes. For Yanks (1979), Richard Rodney Bennett prevented his own march tune from lapsing into cliché by utilizing a Brittenlike dissonant bass line, much as fellow British composer Benjamin Frankel had done in his elaborate and inventive score for Ken Annakin's epic US filming of The Battle of the Bulge back in 1965. But 1977, the year in which A Bridge Too Far was released, had also seen the release of Sam Peckinpah's relentlessly violent Anglo-German production Cross of Iron (sparsely scored by US composer Ernest Gold), and the controversial director's trademark brutality lent the genre a new level of viewing discomfort which would be revisited and modified by filmmakers in later decades.

The significance of A Bridge Too Far for the genre should not, however, be underestimated. Remarkably, considering its frank depiction of such a shambolic defeat, the film received official backing from the Armed Forces because, as S. P. MacKenzie puts it, the project clearly showed how, cinematically, 'the Second World War had finally become history' ${ }^{78}$ As the public taste for both epic-scale recreations of real battles and escapist action-adventures with a wartime setting continued to wane, the combat genre's influence remained crucial in the hugely lucrative family-oriented blockbusters of the New Hollywood. For example, many critics have noted how elements of The Dam Busters, 633 Squadron and Where Eagles Dare appear to have directly inspired the attack on the Death Star in Star Wars (1977), Williams's score for which contains a melodic strain strongly reminiscent of Elgar and Walton in the trio section of its 'Throne Room' march. If Star Wars hero Harrison Ford's acting career was hardly helped by Force 10 from Navarone in the following year (a story for which the film rights had been secured in 1968 but which took ten years to reach the screen

${ }^{78}$ MacKenzie, British War Films, 158. 
owing to diminished public interest in such war-set adventures in the Vietnam era), ${ }^{79}$ the same was certainly not true of his star participation in the Indiana Jones series, launched with Raiders of the Lost Ark in 1981. This franchise skilfully revitalized the action-adventure impulse in a patently fantasized take on a period wartime setting, and once more gave Williams the chance to write a splendid - and decidedly American - march of the kind which helped put the traditional nondiegetic orchestral score firmly back on the broader Hollywood map.

${ }^{79}$ Bond and Kendall, 'A Return to Force', 3-4. 